\title{
Inventory Management Analysis and Improvement of Inventory Control Procedures: Case Study in the Secretariat of the Tax Court
}

\author{
Ferry Andika Harmen ${ }^{1}$, Rafika Yuniasih ${ }^{*}$ \\ ${ }^{1}$ Faculty of Economics and Business, Universitas Indonesia, Depok 16424, Indonesia \\ *rafikausman@gmail.com
}

\begin{abstract}
This study aims to analyze the inventory management and propose improvements to inventory control procedures at the Secretariat of the Tax Court. This study used a qualitative method with case study approach. This study describes the facts relating to inventory management activities, associated with the procurement planning, receipt of inventory, storage and maintenance, distribution of inventory, and record keeping. The results showed there are still weaknesses in the inventory management and control procedures. Therefore, this study proposes the improvement of inventory control by applying the calculation of buffer stock and reorder point, and make improvement to the procedures of; supplies admission; storing and maintenance; distribution procedure; and record keeping.
\end{abstract}

Keywords: ABC Analysis; Inventory Control; Internal Control; Inventory Management; Reorder Point; Safety Stock.

\section{INTRODUCTION}

The Secretariat of the Tax Court has the duty to provide services in the areas of administration, personnel, finance, household, administrative preparation of appeals and/or lawsuits, administration of trial preparation, trial administration, administration of completion of judgments, documentation, administrative review, administrative jurisprudence, and information services. With an increasing number of appeals and decisions of the Tax Court, there are increased operational needs for office supplies (supplies) to support an increase in the settlement of the tax court decision.

Therefore, in order to support effective and efficient tax dispute settlement services, there must also be effective management of operational inventory to facilitate the obtaining of sufficient, adequate, and timely inventory.

Inventory control involves a sequence of closely linked activities throughout the company's production operations in accordance with the planning conducted in advance in terms of time, quantity, quality, and cost ${ }^{1}$.

Furthermore, regulations state that the management of state/regional goods must be carried out based on functional principle, legal certainty, transparency and openness, efficiency, accountability, and certainty of value. Furthermore, paragraph (2) explains that the administration is part of the management of BMN. Orderly administration of BMN is capable of realizing the management of orderly, effective, and optimal BMN.

Furthermore, in the state management of finances, the head of institution as a user of the budget and goods must have an internal control system in their respective government ${ }^{2}$. The Tax Court Secretariat has drafted a policy and procedure (SOP) as a form of control/supervision related to inventory management. However, no draft procedure has been established to date, and problems related to inventory management at the Tax Court Secretariat have not been overcome. This research was conducted with the aim of analyzing the current inventory management and control and proposing improvements to the draft policies and procedures (SOP) related to inventory management.

\section{LITERATURE REVIEW}

Agency theory is a theory that explains the relationships between principals and agents, having its roots in economic theory, decision theory, sociology, and organizational theory. The theory analyzes the contractual arrangements between two or more individuals, groups, or organizations. One party (the principal) enters into a contract, either implicitly or explicitly, with another party (the agent) in the hope that the agency will lead to the performance of such tasks as desired by the principal (in this case delegated authority). Delegation occurs when a person or group of people select another person or group to act in the interests of the principal ${ }^{3}$.

Agency theory can be applied to public sector organizations. The modern democratic state is based on a series of principal-agent relationships, which is linked to work by previous study that explains the economics of public sector organizations using agency theory ${ }^{4}$. The principal-agency relationship framework is a very important approach for analyzing public policy commitments. The preparation and implementation of public policy is affected by contractual issues, namely asymmetric information, moral hazard, and adverse selection ${ }^{5}$.

In government there are principal-agent agreements that can be traced throughout the budget process: 
voters-legislators, legislature-government, finance minister-budget users, prime minister-bureaucrats, and also between officials in service providers ${ }^{4}$. The same was stated by previous studies, which examined the agency relationship as a relationship of delegation (chains of delegation), the delegation of the community to its representatives in parliament, from parliament to the government, the government as a whole to ministers, and from government to bureaucracy, ${ }^{6,7}$.

Inventory management is an activity related to the planning, implementation, and monitoring of material needs so that needs related to operating activities can be met in time and optimal amounts of inventory can be maintained $^{8}$. He also explained that inventory management can be defined as the sum total of those activities necessary for the acquisition, storage, sale, disposal, or use of materials ${ }^{9}$. Inventory management is an enterprisewide discipline concerned with the identification and tracking of Information Services (IS) hardware and software assets. Its three main areas of concern are acquisition, redeployment, and termination ${ }^{10}$. Based on these definitions, inventory management (inventory control) is linked to all necessary activities in the acquisition, storage, handling, use, or removal of inventories.

ABC analysis (Always, Better, Control) is used in inventory systems to analyze patterns of consumption and the amount of total consumption. ABC analysis is the application of inventory in line with the Pareto principle, which suggests the existence of a relatively few important things alongside many more that are relatively less important. $\mathrm{ABC}$ analysis thus aims to create inventory policies that focus inventory on the few important parts of inventory ${ }^{11}$. ABC analysis can classify all types of goods based on their importance. It is determined based on the annual requirement of each item of inventory multiplied by its cost. Inventories are classified into 3 (three) categories $^{11}$; Group A (always), with a cumulative percentage of the investment of 0-80\%; Group B (better), with a cumulative percentage of the investment of $81-95 \%$; and Group C (control), with a cumulative percentage of the investment of $96-100 \%$.

Safety/buffer stock is additional inventory that is maintained to protect against the possibility of shortages (stockout) ${ }^{12}$. If it is difficult or impossible to determine the cost of running out of stock (stockout), managers can adopt policies to maintain the availability of inventory based on a specified level of customer service. Assuming that the demand during lead time (reservations) follows a normal curve, then only average usage and standard deviations are required to determine the amount of safety stock at each level of service ${ }^{13}$. Safety stock can be determined as follows:

$$
Z=(x-\mu) / \sigma
$$

The reorder point is the level of inventory at which immediate action is required to replenish the level of supplies. It is the level of existing inventory that triggers a new order and is expressed as follows ${ }^{8}$ :

$$
R O P=d \times L
$$
follows ${ }^{14}$ :

If an amount of safety stock is held to reduce the occurrence of stockout, the reorder point is expressed as

$$
R O P=(d \times L)+S S
$$

Purchases of the required raw materials must be made or ordered in advance on the basis of periodic calculations. Inventory planning relates to the determination of inventory composition, timing, and location to meet the projected needs ${ }^{15}$. Planning of the needs of state/regional property must be capable of linking the availability of goods as a result of past procurement with the ongoing situation as the basis of future actions in order to achieve efficiency and effectiveness of the management of state/regional goods ${ }^{2}$.

Public procurement concerns the acquisition of goods and services that is carried out by the government or public sector organizations. The terms procurement and purchasing are often used interchangeably in the various literature. Procurement and purchasing refer to similar activities, with procurement more often associated with processes undertaken by the public sector and purchasing with those undertaken by the private sector. ${ }^{16}$ Yet references to procurement activities are seen more widely than those to purchasing activities. Procurement includes purchasing and an option buying cycle between buying and creating. ${ }^{17}$

The receipt of goods in the absence of a good system for their arrangement can interfere with productivity. ${ }^{18}$ The following elements are important with regard to the receipt of goods: proof of the goods being ordered from the warehouse (to ensure the exact specification of goods ordered); a goods receipt (for billing); proof of reservation checked against physical goods; check of expiry date and condition; and insertion of items to storage.

A well-organized storage space will have restricted access, a good layout, and storage racks/containers with accurate labels in which fixed amounts can be kept. ${ }^{11}$ Careful storage must meet the following criteria ${ }^{12}$ : goods are kept by approximate number; frequency of material use; the nature, size, and shape of the material.

To obtain a full accountability report on the use of inventory, a thorough and systematic procedure is required. According to Matz, all purchasing procedures must be known by the related units within an organization. Such procedures shall be supplemented by forms that have been standardized and agreed upon. ${ }^{12}$

The accuracy of inventory recording is critical to providing service satisfaction to consumers, determining 
the fulfillment of each good, ensuring the availability of goods against demand, and analyzing inventory levels and managing excess inventory. ${ }^{19}$ The inventory recording process provides management with the information needed to ensure accountability and facilitate audit activities ${ }^{20}$. While it is possible for inventory recording to be done manually, in relation to the number and complexity of documents to be addressed, more mechanical methods are needed for greater effectiveness. ${ }^{21}$ Compared to computerized recording, manual inventory recording is very slow and carries a high risk of incorrect data entry. ${ }^{10}$

\section{RESEARCH METHOD}

This study employs a qualitative research methodology. Qualitative research expects to identify a new finding that had not previously existed. ${ }^{22}$ The finding may comprise a description or the description of an object that was previously unclear and that becomes clear after the examination. ${ }^{23}$

Furthermore, this research uses a case study approach, which attempts to explain a phenomenon by engaging in the in-depth study of a case of it. The case in question may relate to an individual, an event, a community group, or an institution/organization. ${ }^{24}$ Case studies are defined as research designs that are found in various fields, especially with regard to evaluation. ${ }^{24,25}$

Observation, interview, and document retrieval are the techniques used in this research. These three techniques are employed with the aim of obtaining mutually supportive or complementary information on the inventory management and control in the Tax Court Secretariat. This research uses informants as a data source based on the criteria of them having mastered the problem, having the required data, and being willing to provide complete and accurate information. The informants are thus the Secretary of the Tax Court as the Budget User Authority; Head of General Affairs; Head of Sub Division of Supplies and Household; Head of Sub Division of Finance; Warehouse clerk; Bookkeeper; and the Organization of procurement of goods/services within the Secretariat of the Tax Court;

This research will perform data analysis using the content analysis technique. This involves studying the answers given by the informants to a list of prepared interview questions and also the records made during the observation of the activities undertaken by the informant.

This study will also conduct ABC analysis calculations to classify inventory based on the level of significance of the service, calculate the reorder point (ROP) and to ascertain the amount of safety stock held within the Secretariat of the Tax Court. The reserve point is calculated based on the formula ${ }^{11}$, while calculation of the safety stock is carried out using customer service level assumptions using the formulas ${ }^{13}$.

Safety stock calculations are not based on calculations to determine the optimal amount of fees due to running out of inventory and the relevant storage cost. This is because of the difficulty of determining these costs in relation to government.

\section{RESULTS AND DISCUSSION Planning and Procurement of goods}

Running out of stocks of supplies is a common occurrence in the planning and procurement of supplies at the Secretariat of the Tax Court. Out-of-stock inventory can arise for a number of reasons, as follows. (i) Implementation of procurement carried out with term: this is done to anticipate the limitations of the warehouse storage and to implement provisions in Perpres 54 related to the empowerment of small entrepreneurs in government procurement; (ii) Delay in the delivery of goods (the existence of lead time) while the stock of inventory is exhausted; (iii) Unpredictability of the output of tax court rulings; (iv) The implemented safeguard policy has not been able to anticipate delays in shipments; and (v) consumption of inventory items.

Based on the results of the research, the inventory manager can perform calculations of ABC analysis to classify all types of goods based on their level of significance. Such ABC analysis makes it easy to define inventory control policies within the Tax Court Secretariat. Based on the analysis from the study it can be seen that there are ten types of significant inventory goods for the tax court service. There is no difference between this result and that obtained following analysis carried out by the PRT head of sub district. Furthermore, these ABC analysis results can be used as the basis for the Secretariat of the Tax Court in inventory control activities.

The results of this study also suggest the need to apply a method of calculation for buffer stock and the reorder point in the policies/procedures related to the planning and procurement of supplies. The calculation of buffer stock can be carried out using the formula ${ }^{13}$. Completing the design of policies and procedures related to the planning and procurement of goods, the calculation of safety stock and the reorder point should be added as part of the implementation of Article 40 paragraph (2) PP 60, namely the documentation of an internal control system that includes administrative policies and guidelines.

\section{Acceptance and Examination of goods}

Based on this research, copies of the minutes of the examination and the minutes of the handover of goods 
are not submitted to the officers handling goods at either the stage of receipt or as part of the inspection of goods at the Secretariat of the Tax Court. This happens because the recipient work committee (PPHP), which also doubles as a warehouse officer, sometimes forgets to submit the documents related to the receipt of goods to the recording officer. Such practices result in the recording of inventory mutations in the inventory book not being done in a timely manner. This may cause the officer to not renew the inventory amount in the inventory book.

The recording of inventory mutation is more often carried out several days/months after the transaction has occurred by first collecting proof of purchase. This is not in accordance with the provisions of the regulations, which state that one of the purposes of inventory administration is to provide accurate and timely information about inventory. The regulations explain that the recording of such important events shall be carried out in an accurate and timely manner. Expenditure on supplies originating from APBN funds is an important event and should thus be accountable. Therefore, it is necessary to improve the procedure for the receipt and inspection of inventory goods.

The results of the research enable improvements to be proposed to the design of procedures for the receipt and inspection of inventory items. There should be 3 (three) copies produced of the minutes of handover (BAST), which should be submitted to the goods management officer so that the recording of inventory mutation can be carried out accurately and on time.

\section{Storage and Maintenance of Goods}

Storage area limitations have become a main problem for inventory management in the Tax Court Secretariat and are characterized by poor access and layout. Some of the interview respondents raised this issue as one of the main topics that needs to be addressed in the future.

In addition to limited space, there is inadequate warehouse security. Access to the warehouse is not restricted and there is currently no CCTV covering the warehouse inventory. Another problem involves the warehouse being used for additional activities that it should not be used for.

Based on the study's observations and interviews, the storage of goods is not being conducted in full accordance with the guidelines in the regulations. The storage of goods has basically been carried out according to the different types of goods. The shelving/storage cabinets are not named/labeled appropriately by the warehouse personnel, although there is consistent placement of goods. However, certain conditions were identified in which the placement of goods was not carried out correctly or properly. Such situations arose when the number of items received exceeded the capacity of the warehouse, meaning some items were stored outside of their regular grouping.

This study proposes restricting access to the warehouse, installing CCTV, and the provision of equipment in the warehouse such as fire extinguishers, pallets, tools such as ladders, medical equipment including masks, and a first aid kit, as detailed in the regulations. Inventory should be prepared in accordance with the groups identified in the ABC analysis and labels made for the goods storage shelves. The current card stock format should be changed and adapted to the format set out in the regulations.

\section{Distribution of Goods Inventory}

The results of the observations and interviews revealed that the recording of any mutation in inventory that emanates from the warehouse is not carried out either accurately or in good time. The board of directors is unaware of the distribution of goods from the warehouse/storage area.

The results reveal that in the draft procedures and practices of the distribution of the goods, form letter requests by warehouse officers are not delivered to the registrar for entry into the inventory book, thus meaning that any update on mutation recording on the mutation books of the inventory is not conducted in a timely manner, which contravenes the provisions of the regulations. Based on the official inventory instructions, the warehouse clerk is authorized to make corrections to a request in accordance with the amount of the supplies, but on the applicable procedures and practices board officials do not know the results of the inventory correction and do not authorize corrections made by the warehouse clerk. This is not in accordance with the provisions of the regulations in which the need is expressed for the function of the authorization of transactions and events that are important.

Based on the results of the research, improvements are proposed to the distribution of goods inventory stage in the draft procedures for the distribution of supplies.

\section{Inventory and Registration}

The process of recording inventory at the Secretariat of the Tax Court is carried out by a warehouse clerk and a clerk who makes the record in the inventory application. The warehouse clerk shall make recordings on the card stock inventory in the warehouse, while the recording clerk shall make recordings in the book inventory through supply applications. In carrying out the recording of inventory through purchase, the warehouse clerk uses a range of documents including letters, contracts, SPK, invoices, receipts, and BAST, while the clerk records the use of the goods request form in the inventory application record. 
The observations and interviews revealed that in relation to some transactions, mutations supplies are not implemented in a timely manner as part of this recording of the application inventory. The recording of mutation goods is more often done on a monthly basis by first collecting evidence of the mutation goods. Such a process allows for the gathering of evidence for the missing items prior to listing in the book inventory. This is because the registration personnel do not always receive a copy of the mutation evidence in the form of either a proof of purchase of goods or a goods request form. Therefore, evidence of mutations-related transactions entered through the purchase of goods and the movement of goods through to the demand for goods should be submitted to the recording clerk.

One such activity would be to conduct an inventory of inventory stock taking. In the design of the inventory procedure and recording of inventory in the Secretariat of the Tax Court activity, an inventory check has been included when compiling the inventory report. Based on the interview activities, stock taking has been implemented in the reporting of inventories since 2015. Prior to 2015 there was no inventory check implemented, which is not in accordance with the provisions set out in the regulations.

The results of the study suggest improvements need to be made to the internal control procedures related to the delivery of goods, transaction evidence mutations, increasing supervision carried out by authorized users, the physical examination of goods in relation to the activities of each semester, and the recording procedures in the book inventory.

\section{CONCLUSION}

Based on the research results there remain some obstacles and problems related to the management and inventory control at the Secretariat of the Tax Court. In the planning phase and procurement of goods, managers are faced with the frequent occurrence of supplies running out prior to new procurement being conducted, which is not in accordance with the objectives of goods, namely that goods managers are expected to seek supplies in sufficient condition. In the stages of acceptance and inspection of goods, supplies mutation recording of the results of the procurement in the book inventory is not done accurately and on time, meaning that the inventory manager is unable to provide information that is accurate and timely and is also unable to support the implementation of SAPP in generating inventory information. At the warehouse management stage, storage and distribution is not organized in such a way as to allow the easy identification of materials, or for these materials to be searched, retrieved, monitored, and delivered. In the distribution phase of recording inventory out of the warehouse, inventory mutation is not performed accurately and on time, and the distribution of goods from the warehouse/storage area is not known by the inventory manager. As a result, inventory transactions are not performed consistently. Stocktaking activity is also not carried out consistently, resulting in the inventory manager not knowing the condition and value of the goods. Furthermore, it is known that inventory mutation recording at book inventory is done neither accurately nor on time.

To address these problems the research proposes improved inventory control procedures at the Secretariat of the Tax Court, as follows: the performance of ABC analysis to classify all types of goods based on their level of significance; calculating buffer stock and the reorder point as efforts and methods of computation added to complete the design and procurement planning procedures that have previously been prepared; improving the design of the admission procedures and inspection of goods inventory so that the recording of inventory mutations can be done accurately and on time; restricting access to the warehouse and installing CCTV, adding tools to the warehouse such as fire extinguishers, pallets, tools such as ladders, creating labels, arranging goods according to the groups in the $\mathrm{ABC}$ analysis, changing the format of the cardstock to refer to PMK 113, adding further manpower, and the creation of procedures for the storage of supplies; fixing the distribution stage in the design of procedure supplies for the distribution of goods; the creation of recording procedures in the book inventory and improving the supervision carried out by authorized users on the physical inspection of goods against the activities performed every semester.

\section{REFERENCES}

[1] S. Assauri. Manajemen produksi dan operasi. Fourth edition, BPFE, Surabaya (2004).

[2] A. Mergantara, I. Dodi, and S. Kuwat. Manajemen perbendaharaan pemerintahan, Aplikasi di Indonesia, LSKPAP, Jakarta (2006).

[3] Lupia and M. McCubbins. Representation or abdication? How citizens use institutions to help delegation succeed. European Journal of Political Research, 37 (2000) 291-307.

[4] T. M. Moe. The new economics of organization. American Journal of Political Science, 28(5) (1984) 739-777.

[5] A. Syukriy. Perilaku oportunistik legislatif dalam penganggaran daerah: Pendekatan principal-agent theory, Presented in Seminar Antarbangsa di Universitas Bengkulu, Bengkulu, 4-5 Oktober (2004).

[6] F. Gilardi. Principal-agent models go to Europe: Independent regulatory agencies as ultimate step of delegation. Paper presented at the ECPR General Conference, Canterbury, UK, (2001).

[7] K. Strom. Delegation and accountability in parliamentary democracies. European Journal of Political Research, 37(2000) 261-289.

[8] R. Indrajit and R. Djokopranoto. Manajemen persediaan, Grasindo, Jakarta (2005).

[9] J. W. Prichard and R. H. Eagle. Modern inventory management. John Wiley and Sons Inc, New York (1965). 
[10] T. Bronack. Inventory Management System, McGraw Hill, New York (2012).

[11] R. Heizer. Operations management sustainability and supply chain management, Eleventh Edition, Pearson Education Limited, Edinburgh Gate, Harlow (2014).

[12] F. Rangkuti. Manajemen persediaan aplikasi di bidang bisnis, PT Raja Grafindo Persada, Jakarta (1996).

[13] R. Heizer. Productions and operations management strategies and tactics, Allyn and Bacon Inc, Massachusetts (1988)

[14] T. Horngren, S.M. Datar, and F. Gerge. Akuntansi biaya penekanan manajerial, Edisi Bahasa Indonesia, Indonesia, Indeks, 2 (2008)

[15] Rapiana and L. Christyanto. Peranan sistem pengendalian internal dalam meningkatkan efektifitas dan efisiensi kegiatan operasional pada siklus persediaan dan pergudangan. Akurat Jurnal Ilmiah Akuntansi, 6(2) September-Desember (2011)

[16] N. Caldwell, E. Bakker. Procurement process in the public sector: An international perspective. In Thai, K. (Ed.) International Handbook of Public Procurement. Boca Raton: Taylor \& Francis Group (2009).

[17] J. G. Murray. Towards a common understanding of the differences between purchasing, procurement and commissioning in the UK public sector. Journal of Purchasing and Supply Management, 15(3)(2009) 198-202.

[18] B. Rahardjo. Keuangan dan Akuntansi untuk Manajer Non Keuangan, Edisi Pertama, Penerbit Graha Ilmu, Yogyakarta (2007).

[19] T. Susan, K. Michael. TCRP Research Results Digest, Number 40, October (2000).

[20] J. N. Kariuki. An assessment of the factors influencing effectiveness of inventory control: ministry of state for provincial administration and internal security, Nairobi-Kenya, International Journal of Business and Commerce, 3(1) (2013) 33-53.

[21] D. Jessop, A. Morrison. Storage and supply of materials: (6 $6^{\text {th }}$ ed), London: Financial Times, (1994).

[22] M. B. Miles, A. M. Huberman. Qualitative Data Analysis: A Sourcebook of New Methods, California: SAGE Publications Inc, (1984).

[23] Emzir. Metodologi Penelitian Kualitatif:Analisis Data, Raja Grafindo, Jakarta (2010).

[24] S. Wahyuni. Qualitative research method: theory and practice, Salemba Empat, Jakarta (2012).

[25] R. K. Yin. Applications of case study research ( $3^{\text {rd }}$ ed.). Washington DC: SAGE Publications Inc, (2012). 